PEMANFAATAN SISTEM GAGASAN KOMUNITAS SKOUW SAE, KOTA JAYAPURA

(The idea system within the Skouw Sae community, Jayapura City)

\title{
La Usman
}

Balai Besar Pendidikan dan Pelatihan Kesejahteraan Jayapura (BBPPKS) Jayapura

Jl. Gerilyawan No. 155 Abepura, Kota Jayapura

e-mail: lausman_03@yahoo.com

INFO ARTIKEL

Histori Artikel

Diterima : 19 Agustus 2019

Direvisi : 30 Agustus 2019

Disetujui : 29 November 2019

\section{Keywords:}

system of ideas, needs

fulfillment, Skouw Sae community

\section{Kata Kunci:}

sistem gagasan, pemenuhan kebutuhan, komunitas Skouw Sae

\section{ABSTRACT}

The idea system within the Skouw Sae community, Muara Tami District, Jayapura City plays an important role in fulfilling their basic needs. This study analyzes what kind of ideas system is found in the society. The data were processed using qualitative analysis. The results of the study found three types of ideas systems. The first, which is sourced from the knowledge in culture, such as: the knowledge that comes from the traditional house of tangfa, the position of the land in society, the work behavior, the money as the symbol of the head payment, the work behavior, the money as the symbol of the head payment, Hoo as a symbol of the regulation of natural resource utilization, prohibition of liquor, arisan education as a behavior support the completion of higher education, beads and money as a symbol of dowry, behavior in kinship, shamanism and the symbol of village administration. Secondly, which is based on beliefs and religions, such as: order or kati as a symbol of belief and parade of Easter and Christmas torches as a religious behavior. Third, sourced from sports, arts and ceremonies, such as sports, bajo dance, wo and mandep as a symbol of art and ceremonial behavior around the circle of life.

\section{ABSTRAK}

Sistem gagasan dalam komunitas Skouw Sae, Distrik Muara Tami, Kota Jayapura memegang peranan penting dalam memenuhi kebutuhan dasar mereka. Penelitian ini menganalisis apa saja sistem gagasan yang terdapat pada masyarakat tersebut. Data diolah menggunakan analisis kualitatif. Hasil penelitian menemukan tiga jenis sistem gagasan. Pertama, yang bersumber pada pengetahuan dalam budaya, seperti: pengetahuan yang bersumber pada rumah adat tang $f a$, kedudukan tanah dalam masyarakat, perilaku kerja, uang sebagai simbol pembayaran kepala, perilaku kerja, uang sebagai simbol pembayaran kepala, Hoo sebagai simbol pengaturan pemanfaatan sumber daya alam, pelarangan minuman keras, arisan pendidikan sebagai perilaku mendukung penyelesaian pendidikan tinggi, manik-manik dan uang sebagai simbol mas kawin, perilaku dalam kekerabatan, perdukunan serta simbol pemerintahan kampung. Kedua, yang bersumber pada kepercayaan dan agama, seperti: tata atau kati sebagai simbol kepercayaan serta pawai obor Paskah dan Natal sebagai perilaku keagamaan. Ketiga, yang bersumber pada olah raga, kesenian dan upacara, seperti olah raga, tarian bajo, wo serta mandep sebagai simbol kesenian serta perilaku upacara sekitar lingkaran hidup. 


\section{PENDAHULUAN}

Kegiatan ekonomi (berkebun, berdagang kecil, melaut, meramu, serta berburu) wargakomunitas Kampung Skouw Sae, Distrik Muara Tami, Kota Jayapura sangat penting untuk memenuhi kebutuhan dasar mereka. Beberapa kebutuhan dasar tersebut seperti pemenuhan kebutuhan pangan keluarga, mendukung kegiatan pembayaran mas kawin keluarga lelaki ke keluarga perempuan untuk kebutuhan reproduksi guna mempertahankan kontinyuitas kelompok. Untuk kegiatan pembayaran kepala (denda) kepada seorang suami yang istrinya meninggal, lalu bantuan ini diberikan kepada keluarga istri guna memenuhi kebutuhan kenyamanan dan kesejahteraan keluarga yang bersangkutan. Juga mendukung kegiatan syukuran pembangunan rumah kuburan, rumah adat serta penobatan ondoaf di wilayah Wutung untuk memenuhi kebutuhan kenyamanan dan kesejahteraan individu dan keluarga dari unsur pemimpin tradisional (ondoafi, pesuruh dalam, pesuruh luar serta pimpinan klan) yang oleh Georges Balandier dalam Budisanto (1986: 51) menyebutnya sebagai kewenangan sosial dalam bentuk melindungi, menjaga, menyelesaikan masalah kesalahpahaman yang terjadi di antara anggota klannya, mengatur pemanfaatan lahan bagi anggota klannya serta menunjang anggota keluarga klannya yang meninggal dengan cara memberikan lahan untuk aktivitas ekonomi. Juga untuk mendukung pembelian minuman kaleng pada perayaan Natal guna memenuhi kebutuhan keselamatan melalui proteksi dan pertahanan secara keagamaan. Juga menunjang kegiatan syukuran perbaikan rumah adat dengan tujuan memenuhi kebutuhan keselamatan dari semua bahaya yang mengintai, mendukung kegiatan piknik keluarga tiap liburan sekolah untuk memenuhi kebutuhan relaksasi individu. Selain itu, menunjang kegiatan kunjungan pembangunan rumah kuburan, perbaikan rumah adat serta penobatan ondoafi dengan tujuan memenuhi kebutuhan relaksasi melalui dansa adat bersama. Juga mendukung kegiatan pertukaran hadiah antara perempuan kedua kampung untuk memenuhi kebutuhan relaks serta mempertahankan relasi di antara mereka serta mendukung kegiatan pertandingan bola kaki dan bola voli dalam bingkai persahabatan untuk memperingati HUT PNG dengan tujuan memenuhi kebutuhan relaksasi. Selain itu, memenuhi kebutuhan gerakan mendekatkan hubungan antara kepala kampung guna mempertahankan peran keduanya dalam peningkatan kesejahteraan sosial warganya serta untuk memenuhi kebutuhan pertumbuhan individu melalui kegiatan pendidikan formal. Maka peran sistem gagasan sangat besar dalam mendukung beberapa pemenuhan kebutuhan di atas.

Maka permasalahannya yang ingin diteliti adalah pertama, apa saja sistem gagasan yang yang bersumber pada pengetahuan budaya? Kedua, apa saja sistem gagasan yang bersumber pada agama? Ketiga, apa saja sistem gagasan yang bersumber pada seni, olahraga, 
permainan, serta upacara yang mendukung pemenuhan kebutuhan di atas?

Penelitian ini berlangsung dari bulan September 2014 hingga Juni 2015 di Kampung Skouw Sae, Kota Jayapura dan Wutung PNG dengan menggunakan metode kualitatif dengan rancangan penelitian bertujuan mengetahui peran sistem gagasan warga dalam menunjang kegiatan ekonomi. Perolehan data menggunakan observasi partisipasi serta wawancara dengan individu-individu warga kedua kampung. Prosedur penelitian, pertama, membuat pedoman wawancara dengan dengan menekankan pada pengalaman hidup (life history) informan. Kedua, menelaah seluruh data dari berbagai sumber. Ketiga, data direduksi. Keempat, data diabstrasikan, disusun dalam satuan, kemudian data dikodifikasi secara sederhana berdasarkan permasalahan dan penelitian. Kelima, data diperiksa kembali keabsahannya. Keenam, data yang diperoleh disusun berdasarkan tema-tema kegiatan dengan uraian deskriptif. Dengan cara demikian diharapkan dapat diperoleh hasil kajian yang akurat.

\section{Konsep Sistem Gagasan}

Menurut Malinowski dalam Turner (2010: 95) bahwa kebutuhan sistem gagasan (simbolis) merupakan salah bagian yang tidak dapat dipisahkan dari kebutuhan dasar manusia. Ketika manusia secara kolektif berusaha mengatasi kebutuhan dasar dan instrumentalnya, mereka juga telah menciptakan sistem lambang (gagasan). Selama beraktivitas sehari-hari, mereka menghasilkan sistem gagasan yang digunakan untuk mengabsahkan, mengatur dan menuntun perilaku mereka. Oleh sebab itu, lambang digunakan untuk memadukan dan merekatkan bersama lembaga dan kumpulan lembaga ke dalam suatu keutuhan yang padu. Menurut Malinowski dalam Turner (2010: 96) terdapat tiga jenis kebutuhan integratif yang telah diderivasikan. Pertama, kebutuhan suatu anggota masyarakat untuk memiliki, menggunakan, dan meneruskan suatu sistem prinsip untuk menghadapi dunia sekitar mereka. Dia memandang "pengetahuan" dalam suatu budaya sebagai sistem lambang yang memenuhi kebutuhan ini. Kedua, kebutuhan suatu anggota masyarakat untuk memiliki suatu rasa bahwa diri merekalah yang mengendalikan nasib mereka sendiri dan menciptakan peristiwa-peristiwa yang terjadi di dunia sekitar mereka. Malinowski memandang agama dan ilmu magis sebagai sistem lambang utama yang memenuhi kebutuhan ini. Ketiga, kebutuhan suatu anggota masyarakat untuk sama-sama memiliki "ritme komunal" dalam kehidupan dan aktivitas mereka. Malinowski memandang kebutuhan ini dipenuhi oleh sistem pemikiran yang memandu seni, olahraga, permainan, dan upacara. Dalam implementasinya pemenuhan keempat kebutuhan simbolisme tersebut dapat berjalan berbarengan bagi individu setempat. Maka pendekatan Malinowski di atas akan digunakan sebagai dasar untuk memahami sistem gagasan yang 
dimanfaatkan untuk menunjang kegiatan ekonomi warga komunitas Kampung Skouw Sae.

\section{Kebutuhan Lahirnya Sistem Gagasan}

Sistem gagasan pada dasarnya merupakan salah satu unsur kebutuhan dasar setiap warga komunitas Skouw Sae yang tumbuh bersamaan dengan berbagai unsur lainnya lalu membentuk kepribadian seseorang, misalnya hasrat, nafsu, emosi, benci, cinta, puas, rasa bersalah dan berbagai sikap lainnya. Meskipun demikian, pola pengaktifannya selalu dipengaruhi oleh lingkungan kebudayaannya di mana individu itu berada. Karena lingkungan manusia selalu kolektif, gagasan-gagasan dan pola tindakan kolektif mengubah orientasi perilaku bersama. Hal ini berarti sistem gagasan diciptakan untuk mendukung pemenuhan kebutuhan warga menurut pola-pola kebudayaan setempat. Sistem gagasan seperti ini dapat kita terjemahkan sebagai upaya atau langkah untuk memberi makna sebuah kegiatan dalam memenuhi kebutuhan hidup, melakukan kewajiban sosial seperti membayar harta maskawin, membayar harta kepala dan lain sebagainya.

Oleh karena itu, sistem gagasan tersebut dibangun melalui aturan-aturan yang berlaku dalam kehidupan sehari-hari, mengaktifkan simbol bahasa, membuat kategori sosial (orang dalam dan orang luar), menggunakan istilah-istilah tertentu dalam membangun komunikasi yang intens dan akrab, serta membangun batas-batas sosial dan fisik dalam rangka membedakan diri dengan orang lain sekaligus agar merasa lebih aman (secure) terhadap berbagai dinamika pembangunan yang menyertainya. Pola pengaktifan sistem gagasan tersebut didasarkan pada konteks kebudayaan setempat. Unsur-unsur seperti ini diinternalisasi sejak kecil sehingga menghasilkan kepribadian yang sesuai dengan kebudayaan setempat. Internalisasi nilai demikian terus disosialisasikan dalam keluarga dan dalam pendidikan tradisional dalam rumah adat dari generasi ke generasi dalam kehidupan komunitas, sehingga memunculkan kepribadian yang berbeda dengan orang lain. Secara bersamaan cara ini sangat penting dalam mendukung pemenuhan dasar demi menjaga keberlangsungan individu, keluarga, klan serta komunitas secara umum.

\section{PEMBAHASAN}

Sistem gagasan yang bersumber pada Rumah Adat Tangfa.

Rumah adat tangfa dalam komunitas Skouw Sae dikenal sebagai pusat pendidikan atau pengajaran bagi kaum lelaki. Seorang lelaki dalam komunitas ini memiliki peranan yang besar dalam kehidupan keluarga, klan dan komunitas. Untuk dapat melakukan peran yang demikian maka ia perlu disiapkan dengan berbagai pengetahuan (sistem gagasan) yang diperlukan. Oleh karena itu, rumah adat digunakan sebagai tempat penyiapan bagi para lelaki agar mereka agar dapat memikul tanggung jawab yang diemban dengan baik. Penyiapan 
itu berupa pembelajaran terhadap berbagai aspek yang dirumuskan dalam bentuk pengetahuan. Materi pewarisan pengetahuan dasar meliputi lima aspek. Pertama, aspek kesehatan, terutama yang menyangkut masalah kesehatan diri (dalam arti sehat tubuh dan mental) dan kesehatan lingkungan. Kedua, upaya penumbuhan perilaku rajin dengan cara menghilangkan sifat malas, santai, masa bodoh, serta terlalu banyak tidur. Ketiga, upaya penumbuhan perilaku kebersamaan melalui penciptaan pola hidup yang baik untuk mencapai kebahagiaan secara kolektif. Keempat, upaya penciptaan keterampilan secara individu maupun kolektif untuk aktivitas ekonomi. Sementara itu, keterampilan untuk anak wanita diajarkan cara pembuatan noken, alat penangkap ikan (lae-lae), mengasuh anak, bercocok tanam, menyiapkan makan dan lain sebagainya. Kelima, penumbuhan sifat ketabahan dalam mewujudkan apa yang dicita-citakan. Keenam, pengenalan kepercayaan seruling suci (puu) yang merupakan suatu tanda keberkahan serta keharusan menjaga rahasia benda-benda keramat seperti kelambat, tifa, tembikar (tempaa), serta rahasia rumah adat lainnya yang menjadi identitas komunitas ini bagi setiap lelaki.

Pengetahuan lanjutan yang diberikan meliputi delapan hal. Pertama, cara pemanfaatan tumbuhan sebagai bahan sandang, pangan dan papan. Terdapat 36 jenis tanaman untuk dimanfaatkan sebagai pangan, sandang serta papan. Kedua, berburu dalam bentuk kolektif dan individu dalam kehidupan sehari-hari. Ketiga, bercocok tanam dengan tahapan pemilihan lahan, penebangan pohon, pembakaran, penanaman, perawatan, pemanenan, serta masa pasca panen. Keempat, pemeliharaan babi. Kelima, melaut sebagai kegiatan tambahan untuk menambah protein keluarga. Keenam, pengenalan pemanfaatan kawasan lingkungan menurut kegunaannya. Ketujuh, tentang kesenian yang menyangkut seni suara, seni tari dan seni hias. Kedelapan, pengenalan sistem sosial kemasyarakatan yang meliputi hubungan kekerabatan dengan pihak ayah dan ibu, harta waris atas tanah, dan tanggung jawab seorang anak lelaki. Juga pengenalan sistem perkawinan yang meliputi pengenalan klan, tanggung jawab untuk meminang seorang gadis, ketentuan pembayaran mas kawin, serta jenis mas kawin yang digunakan. Dalam kaitan struktur pemerintahan adat diajarkan tentang hak waris jabatan, tugas dan tanggungjawab unsur pimpinan tradisional (barite, pesuruh dalam, pesuruh luar, para pimpinan klan). Juga diajarkan pengetahuan tentang keyakinan dan agama. Wawasan pengetahuan lanjutan bagi seorang perempuan menyangkut kehamilan, kelahiran seorang anak, masa kanak-kanak, masa inisiasi, masa pemuda, berumah tangga, serta kematian.

Menurut Koentjaraningrat (1984: 46) dalam pola pembinaan secara berjenjang tersebut juga dimaksudkan sebagai proses sosialisasi. A. Van Gennep menyebutnya sebagai rites de passage atau ritus peralihan. Hal tersebut disebabkan 
pada semua masa perkembangannya, manusia selalu bergerak dari lingkungan sosial yang lama ke lingkungan sosial yang baru. Dalam proses peralihan itu, manusia bisa mengalami sakit, maut, serta bencana. Dalam menghadapi kondisi seperti itu, menurut Koentjaraningrat manusia harus bersikap waspada, memperteguh imannya, serta memperkuat mentalnya. Oleh karena itu, ia perlu disiapkan secara baik untuk menghadapi kondisi tersebut.

Dengan demikian pengetahuan komunitas ini sebagai sistem gagasan mempunyai makna yang sangat penting. Oleh karena meletakan dasar pemenuhan kebutuhan ekonomi dan kontrol sosial. Dasar pemenuhan kebutuhan pertama berupa keterampilan bercocok tanam, berburu, pemeliharaan hewan, serta nelayan. Sementara itu, dasar pemenuhan kebutuhan kedua berupa nilai-nilai yang primer sifatnya. Penanaman dasar pemenuhan kedua kebutuhan tersebut dengan diikuti sanksi adat pada tingkat implementasi, telah berhasil membangun kesadaran akan hak dan kewajiban setiap orang sejak dini untuk menjaga dan melestarikan komunitas ini. Ketiga, pewarisan pengetahuan juga memegang penting dalam menguatkan keberadaan pemimpin tradisional dalam kehidupan komunitas ini.

Maka pengetahuan adalah suatu bentuk kesadaran warga mengenai pentingnya bekal bagi seorang lelaki untuk menjaga kesinambungan keluarga, klan dan komunitas secara umum. Pengetahuan adalah suatu peristiwa manakala manusia menyadari relasinya dengan apa yang diketahuinya. Maka kesadaran itu dapat diartikan sebagai seluruh usaha dan hasil usaha manusia dan komunitas untuk mencukupisegalakebutuhan sertahasratnya untuk memperbaiki nasib hidupnya. Usaha tersebut terungkap baik dengan mengolah lingkungan dan dunianya untuk memenuhi kebutuhan tersebut, maupun dengan menciptakan pola dan hubungan komunitasnya yang mempermudah dan memperlancar pergaulan hidupnya. Menurut Poespowardojo (1989: 121) usaha ini terlaksana dengan memberikan makna manusiawi kepada benda yang diolahnya dan membuat tata kehidupan komunitas menjadi lebih baik. Juga dapat melestarikan keberlangsungan kehidupan individu, keluarga, klan serta komunitas secara umum.

\section{Kedudukan Tanah dalam Masyarakat}

Salah satu tekanan secara selektif pada sistim gagasan dalam pemenuhan kebutuhan pangan adalah tanah. Tanah (hitama) merupakan aspek penting dalam memenuhi kebutuhan dasar tiap individu serta keluarga komunitas ini. Dari aspek ini pula dilakukan pengaturan kegiatan ekonomi serta pemanfaatan sumber daya alam. Oleh karena itu, tanah mempunyai makna penting bagi komunitas ini. Secara umum tanah dipandang sebagai mama atau ibu yang melahirkan, memberi makan, memelihara, mendidik dan membesarkan sampai sekarang. Tanah dianggap sebagai rahim dan buah kandung yang membentuk 
dan menciptakan manusia. Kehadiran penyinjil Agustinus Mahulete tahun 1914, telah ikut melahirkan makna agamis tanah sebagai sumber kekuatan, sumber harapan bahkan sumber inspirasi bagi masa depan masyarakat Skouw. Selain itu, tanah juga memiliki aspek historis, mitologi, struktur sosial serta genealogi. Menurut Suparlan (1995: 38). Maka pemanfaatan tanah yang tidak memperhatikan prinsip ini akan berujung pada konflik.

Pada komunitas terdapat pengaturan pemanfaatan tanah (lahan) menurut fungsinya. Pertama, daerah utama (zona inti) yang ditandai dengan rumput hijau yang sering ditutupi embun, dan diyakini sebagai tempat tinggal para penguasa alam setempat. Kedua, wilayah yang padat dengan berbagai jenis pohon dan jenis tali, seperti rotan dan lain sebagainya. Pada daerah ini orang dilarang melakukan penebangan. Anak sungai yang mengalir beserta bebatuan yang terdapat di atasnya, diyakini merupakan mata rantai kelangsungan hidup mereka. Klan Retto sering mengawasi perilaku warga komunitas pada kawasan ini, terutama yang terkait dengan pemanfaatan kayu besi, kayu matoa untuk kepentingan pembuatan rumah, perahu, dan lain sebagainya. Ketiga, daerah yang memiliki tumbuhan berbuah, sehingga sering menjadi lokasi perburuan hewan. Keempat, wilayah perladangan warga disertai dengan pembuatan pagar.

Kepemilikan lahan di wilayah ini dibagi menjadi tiga macam. Pertama, wilayah penguasaan tanah pribadi yang bersumber dari tanah atau lahan yang didapatkan dari warisan keluarga dekat yang meninggal. Kedua, tanah milik klan yang penguasaan dan pengaturan penggunaannya dilakukan pimpinan klan. Ketiga, tanah umum yang pengaturan penggunaannya dilakukan ondoafi. Adanya kepemilikan lahan yang ditandai dengan batas alamiah, maka sering kali lahan-lahan tersebut menimbulkan klaim kepemilikan dari tiap klan. Keberadaan sumber daya alam yang pengaturan pemanfaatannya dilakukan dalam kerangka klan seperti di atas, kini secara perlahan mengalami pergeseran. Kondisi belakangan ini terjadi ketika masuknya investasi ekonomi untuk memanfaatkan sumber daya alam berupa kayu di wilayah ini. Hal tersebut berdampak pada berubahnya sikap para pemimpin klan. Sikap tersebut terlihat dari adanya klaim terhadap hak ulayat tiap klan yang semakin menguat, yaitu upaya untuk mentransformasikan legitimasi hak ulayat untuk memperoleh ganti rugi dari perusahaan hak pengelola hutan (HPH) yang sejak lama beroperasi di wilayah ini. Belakangan, sikap di atas juga merupakan wujud kesadaran pergantian terhadap hilangnya sumber daya hutan yang telah berdampak pada jauhnya lokasi berburu serta meramu bagi tiap anggota klan.

Pada komunitas ini terdapat pula batas tanah (keho) tiap klan secara jelas. Pada komunitas ini, kata tersebut bermakna batas antara 2 pemilik wilayah, baik antarperorangan, antarklan, antarkomunitas ataupun antarnegara. Pemahaman tapal batas secara budaya berpijak pada batas yang sudah ada secara alamiah (natural 
boundaries) yang diwariskan secara turun menurun. Konsep batas seperti ini tercipta dalam konteks ekologis, nilai-nilai struktur sosial, dan mitologi, yang dipercaya atau dianut komunitas pendukungnya. Dengan pemahaman demikian, menurut masyarakat yang memiliki pemahaman batas seperti ini, maka secara ekonomi, segala sumber daya alam seperti kayu dan non kayu yang terdapat di dalamnya, merupakan pemilik wilayah tersebut. Tanda-tanda nyata di atas yang masih diakui bersama didasarkan atas tiga fakta, yaitu pertama, berupa tanda bekas kebun dengan tanamannya, seperti tanaman sagu, kelapa, pinang, dan lain-lain. Kedua, cerita-cerita rakyat yang terkait dengan wilayah itu, seperti perang antar suku untuk mempertahankan wilayah kultural tersebut. Ketiga, nama-nama lokasi sangat terkait dengan bahasa penutur lokal dari komunitas yang bersangkutan. Apabila terjadi silang pendapat tentang tanah adat atau wilayah kultural, bukti faktual di atas dijadikan sebagai rujukan untuk memperkuat gugatan klan tertentu atas suatu wilayah yang disengketakan. Pengaturan pemanfaatan lahan untuk aktivitas ekonomi bagi anggota klan dikuasai dan dilakukan oleh pimpinan klan. Apabila ada warga di luar klan yang ingin mengelola lahan klan lain, yang bersangkutan harus meminta izin terlebih dahulu kepada pimpinan klan sebagai pemilik wilayah tradisional klan'.

Pada sisi lain, dengan adanya usaha pemerintah dalam rangka taat azas, khususnya mengenai pemerintahan desa (UU No. 5/1979) batas kultural seringkali sama dengan batas administratif, sehingga kedua pemahaman batas ini dapat dikatakan tumpah tindih. Batas antarkampung sekarang ditentukan oleh pemerintah ketika dilakukan pemekaran wilayah pemerintahan distrik atau kampung. Batas antara wilayah pemerintahan kampung yang ditetapkan oleh pihak pemerintah berbeda dengan yang ditetapkan oleh pihak adat. Namun, komunitas lokal lebih patuh dan menghargai batas yang telah ditentukan berdasarkan adat, yang kemudian disebut tanah ulayat adat. Dalam banyak hal, penentuan dan penetapan batas wilayah pemerintahan kampung oleh pihak pemerintah selalu dilakukan dengan mendekati tokoh masyarakat dan adat untuk mempertegas batas wilayah kultural tersebut agar tidak terjadi saling tumpah tindih atau saling menyalahkan atas ketetapan yang sudah disepakati. Hal tersebut dianggap penting untuk menghindari kesalahan penetapan garis pembatas antara pemerintahan kampung, agar tidak terjadi masalah antarkampung yang berdekatan secara geografi. Dalam kenyatannya, komunitas pemilik wilayah kultural tersebut berpegang pada batas yang ditentukan oleh pihak adat yang diperkuat oleh pihak pemerintah. Menurut Warren (2002: 240) seiring dengan pelaksanaan era reformasi telah diidentifikasi secara kolektif sumber-sumber daya lokal, polapola kepemilikan dan penggunaan tanah, menelusuri secara historis dan kultural situs-situs signifikan, dan menegosiasikan kontrol individu dan komunitas terhadap sumber daya lokal yang memberikan manfaat bagi komunitas setempat. 
Dari pemaparan di atas diperlihatkan bahwa tanah sebagai sistem gagasan yang digunakan untuk mengabsahkan, mengatur dan menuntun perilaku warga memiliki beberapa manfaat. Dari fungsi pendidikan, tanah dipandang sebagai mama atau ibu yang melahirkan, memberi makan, memelihara, mendidik serta membesarkan. Juga dianggap sebagai rahim atau buah kandungan yang membentuk dan menciptakan manusia sehingga perlu mendapat perhatian yang serius. Dari sisi agamis, tanah dianggap sebagai sumber kekuatan, harapan, bahkan sumber bagi masa depan komunitas Skouw. Fungsi kontrol sosialnya, mengontrol pemanfaatan tanah melalui pembagian wilayah (zone) dengan disertai sanksi yang tegas. Fungsi kelembagaannya, menentukan kekuasaan individu, pimpinan klan serta ondoafi dalam pengaturan lahan. Fungsi strategisnya menjaga keberlangsungan keberadaan kehidupan keluarga, klan dan komunitas secara umum dalam jangka panjang.

\section{Perilaku Kerja}

Salah satu tekanan terhadap pemenuhan dasar adalah lahirnya makna kerja. Konsep etos kerja mengandung pengertian tentang nilai yang melandasi normasosialtentangkerja.Dalampengertian umum, etos kerja dapat diartikan sebagai semangat kerja yang menjadi ciri khas dan keyakinan seseorang atau sekelompok orang. Maka konsep ini mengacu pada watak dasar komunitas kampung ini, yang diwujudkan dalam norma sosial berupa penilaian tinggi terhadap kerja. Dengan kata lain, pengertian ini mengacu pada kegiatan-kegiatan produktif yang dapat menghasilkan sesuatu untuk dinikmati. Penilaian demikian menyebabkan orang yang tidak melakukan sesuatu kegiatan produktif untuk dinikmati, dinilai mempunyai status sosial yang rendah. Oleh karena itu, konsep tersebut mempunyai pemahaman yang berkaitan dengan kegiatan yang menghasilkan pemenuhan kebutuhan dasar.

Bertolak dari pemikiran di atas, maka perilaku kerja individu kampung ini dapat dipahami melalui kegiatan yang dilakukan oleh mereka untuk mempertahankan hidupnya. Perilaku kerjanya adalah bekerja untuk memenuhi kebutuhan dasar untuk jangka panjang. Atau orang bekerja untuk menghasilkan makanan yang cukup untuk kebutuhan selama tanaman berproduksi. Hal tersebut dilandasi pemikiran bahwa hidup ini harus mempunyai persediaan makanan yang cukup untuk dinikmati. Maka tiap keluarga harus bersusah payah mengumpulkan bahan makan secara berlebihan agar dapat dinikmati. Pandangan hidup demikian cukup beralasan, sebab tiap keluarga berfungsi sebagai kelompok produksi melalui pembagian kerja. Kegiatan tegalan memerlukan proses yang lama mulai dari menebang pohon, menanam, merawat hingga memanen hasil. Keseluruhan proses tersebut memerlukan waktu antara enam hingga sepuluh bulan. Fase-fase kerja tersebut memerlukan ketekunan dan kerajinan kerja seseorang. Ini menunjukkan bahwa 
etos kerja komunitas Kampung Skouw Sae dapat dikategorikan sebagai etos kerja keras. Namun harus dicatat bahwa ukuran etos kerja tersebut adalah dalam batas pemenuhan kebutuhan ekonomi rumah tangga sendiri, bukan untuk kebutuhan ekonomi pasar. Maka perlu didorong pemenuhan kebutuhan ekonomi pertama ke pemenuhan kebutuhan ekonomi kedua.

\section{Uang Sebagai Simbol Pembayaran Kepala}

Salah satu tekanan selektif terhadap tuntutan meninggalnya seorang istri atau anaknya adalah dilakukannya pembayaran kepala (kerugian) terhadap keluarga asal si istri, dengan alasan selama hidupnya yang bersangkutan memegang peranan penting dalam pemenuhan kebutuhan seksual suaminya yang dilegalkan melalui perkawinan. Ia juga memiliki peran yang besar dalam urusan reproduksi, domestik bahkan ekonomi serta sering terlibat pada kegiatan rumah adat, keagamaan, sosial dalam dan di luar komunitasnya. Tahapan pembayaran "kepala" ini dimulai dari pertemuan keluarga suaminya beberapa hari setelah kematian yang bersangkutan, lalu dilakukan pengumpulan dana. Umumnya, besarnya nilai kerugian yang diberikan kepada keluarga si istri yang meninggal tergantung dari besarnya bantuan yang terkumpul. Penyerahan 'pembayaran kepala' dilakukan keluarga suami terhadap keluarga istri yang diwakili oleh adik laki-laki si istri.

Maka pembayaran kepala dari keluarga suami kepada keluarga istri memiliki beberapa manfaat. Fungsi ekonominya mengganti kerugian keterlibatannya dalam wujud materi atau nonmateri di lingkungan suami atau komunitasnya. Sementara itu, bagi anggota keluarga yang meninggal, kegiatan pembayaran kepala dianggap sebagai wujud penghargaan terhadap anggota keluarga mereka yang telah memberikan keturunan dan berfungsi selama hidupnya dalam urusan domestik, reproduksi serta ekonomi. Pergantian kerugian tersebut juga didasarkan alasan bahwa kematian berdampak pada hilangnya ikatan dengan keluarga istri mereka. Sementara itu, fungsi pendidikannya merupakan penghargaan terhadap jasa yang bersangkutan terhadap anggota keluarga lelaki. Selanjutnya fungsi kontrol sosialnya, mengontrol suami yang bersangkutan agar bisa merawat dan menjaga istrinya dengan baik. Juga menjaga ketenteraman kehidupan sosial karena dapat menghilangkan benih permusuhan dan menjaga hubungan baik antara keluarga suami dan istri serta kedua komunitas pada umumnya.Terakhir fungsi kelembagaannya, menjaga kelangsungan ikatan kekerabatan suami dan istrinya.

\section{Hoo Sebagai Simbol Pengaturan Pemanfaatan Sumber Daya Alam}

Salah satu tekanan selektif terhadap tuntutan menjaga keberlanjutan komunitas ini adalah munculnya pengaturan pemanfaatan sumber daya alam (hoo) terhadap wilayah laut, sungai, 
telaga dan kawasan hutan dengan segala isinya, termasuk tanaman sagu, kelapa, pinang, dan jenis tanaman tertentu yang telah disepakti bersama oleh pimpinan tradisional. Pelarangan yang selalu diikuti penerapan sanksi bagi yang melanggarnya, berlaku 1 hingga 2 bulan sebelum pelaksanaan kegiatan adat atau gereja yang melibatkan warga dalam jumlah yang banyak. Pelaksanaan hoo selalu diawali dengan ritual yang dipimpin ondoafi dalam bentuk memasang tanda larangan, yaitu menancapkan pelepah pohon enau (gana) pada areal yang sudah ditentukan sebelumnya. Ketika masa hoo dinyatakan berakhir, maka tanda larangan tersebut dicabut dan wilayah pelarangan tersebut dapat dimanfaatkan bersama untuk acara adat atau keperluan warga.

Menurut Coservation International dalam Veplum (2010: 34) ada banyak alasan mengapa harus menjaga (melestarikan) keaneragaman hayati. Masyarakat yang bersangkutan tinggal di daerah pedesaan, pasti lebih mengerti manfaat berbagai jenis flora dan fauna, karena hidup mereka sangat dekat dan sehari-hari bergantung pada pemanfaatan kedua hal tersebut. Selain itu, perilaku demikian sangat penting untuk mencegah pihak luar yang ingin mengeksplorasi dan mengeksploitasi sumber daya alam yang terdapat di wilayah tersebut. Menurut Usman Pelly dalam Veplum (2008: 75) sanksi berfungsi sebagai alat kontrol untuk mengembalikan anggota komunitasnya yang menyimpang kepada tingkah laku yang normal. Sementara itu, menurut Poespowardojo
(1989: 113) sikap demikian itu akan mampu memupuk kesadaran lingkungan dan menghindarkan tindakan pengrusakan yang sewenang-wenang terhadap alam yang akan mengganggu kelangsungan kehidupan keluarga, klan serta komunitas secara berkelanjutan.

\section{Pelarangan Konsumsi Minuman Keras}

Salah satu tekanan terhadap tuntutan kebutuhan rasa aman dalam kehidupan bersama adalah lahirnya pelarangan konsumsi minuman keras. Kebiasaan mengonsumsi minuman keras berawal ketika warga kampung ini berhubungan dengan warga Kampung Wutung dan Kota Jayapura. Efek negatifnya adalah memunculkan perilaku yang mengganggu kalangan ibu rumah tangga. Dalam keadaan mabuk, para pengguna minuman keras sering berkelahi serta melakukan pemukulan terhadap orang lain. Sering munculnya kasus tersebut, mendorong kaum perempuan di kampung ini menggelar demo dengan cara jalan bersama mengelilingi wilayah sekitar kampung dalam keadaan bertelanjang dada. Sikap kaum perempuan tersebut menurut Usman Pelly dalam Veplum (2008: 45) merupakan suatu proses pertumbuhan kesadaran akan dunia sekitar. Kesadaran terhadap sesuatu yang dianggap mengancam eksistensi kehidupan pribadi, keluarga dan kelompok bahkan komunitas yang bersangkutan, sehingga tidak dapat dibiarkan berkembang dan menjadi budaya baru di lingkungannya. Munculnya tuntutan 
tersebut, mendorong tokoh adat dan tokoh agama memutuskan tiga hal. Pertama, tidak dibenarkan menyimpan, mengedarkan atau menjual dan mengkonsumsi minuman keras di lingkungan kampung. Kedua, tidak dibenarkan mengadakan dan mengkonsumsi minuman keras pada setiap ritual apapun di wilayah hukum Kampung Skouw Sae dan sekitarnya. Ketiga, Kepada barang siapa yang melanggar ketentuan tersebut disengaja atau tidak, akan dihakimi massa Kampung Skouw Sae. Implementasi aturan yang tidak mengenal "tebang pilih" berhasil menciptakan ketenteraman dalam kehidupan warga.

Maka terdapat manfaat dari pelarangan tersebut. Fungsi pendidikannya menghilangkan kebiasaan buruk yang sering mengganggu ketenteraman kehidupan komunitas sehari-hari. Juga menyelematkan generasi muda atau perempuan dalam komunitas ini dari ancaman atau kejahatan yang bersifat fisik atau non fisik yang ditimbulkannya. Juga sebagai tindakan perlindungan terhadap sesuatu yang dapat membahayakan eksistensi atau keberadaan komunitas ini. Sebagai pengendalian sosial, pelarangan konsumsi minuman keras juga dapat mempertebal keyakinan warga kampung akan kebaikan pelarangan tersebut, memberi peringatan ganjaran kepada warga yang biasanya taat kepada aturan tersebut, mengembangkan rasa malu dalam jiwa warga yang menyeleweng aturan tersebut serta mengembangkan rasa takut dalam jiwa warga yang hendak menyeleweng dari aturan tersebut dengan ancaman dan kekerasan yang akan diberikan warga. Fungsi ekonominya mencegah pengeluaran pendapatan untuk hal-hal yang tidak perlu. Fungsi kontrol sosialnya, mengontrol ketenteraman dan ketenangan kehidupan warga seharihari agar dapat melaksanakan aktivitas dengan lancar. Fungsi kelembagaannya mendukung pemimpin tradisional, aparat kampung, serta semua elemen masyarakat dalam menegakan pelarangan tersebut.

\section{Arisan Pendidikan Sebagai Perilaku Mendukung Penyelesaian PT} Salah satu tekanan terhadap tuntutan pemenuhan kebutuhan penyelesaian pendidikan tinggi warga kampung ini adalah lahirnya arisan pendidikan. Kebiasaan ini ini muncul karena kesadaran tentang adanya keterbatasan biaya pada tiap keluarga sehingga berdampak pada terbatasnya putra-putri kampung ini yang mampu menyelesaikan pendidikan tinggi di Kota Jayapura. Sehingga diketemukan banyak yang putus kuliah. Bagi seorang yang studi di perguruan tinggi di Kota Jayapura, membutuhkan beberapa item biaya yang bervariasi seperti sumbangan pendidikan, biaya pemondokan, transport, makan, kesehatan, kebutuhan buku dan lain sebagainya, yang mencapai $\mathrm{Rp}$. 12.000.000,0. Dimana semuanya harus ditanggung oleh orang tua siswa yang bersangkutan. Untuk mengatasi kendala tersebut maka diputuskan dilakukan arisan bantuan pendidikan untuk mendukung tingkat dan jenis pendidikan anak dari 
tiap keluarga, terutama untuk tiap manik-manik). Besarnya nilai mas kawin mahasiswa yang akan menyelesaikan studi ditentukan keluarga perempuan walaupun akhirnya. Upaya demikian telah berhasil terdapat proses pertemuan dengan keluarga membantu menyelesaikan beberapa warga lelaki. Manik-manik yang digunakan kampung ini. Keberhasilan tersebut telah terbagi dalam empat kategori yaitu; (1) menjadikan kegiatan arisan pendidikan Tu'ha berwarna biru tua, berbintik, jenis ini sebagai tradisi baru yang kemudian diakui dinilai paling tinggi, (2) Turo papi berwarna sebagai kearifan lokal komunitas ini dalam hijau, Turo pala berwarna putih, jenis ini dunia pendidikan. Dan pola demikian telah diikuti pula warga Kampung Skouw Mabo dan Skouw Yambe.

Maka terdapat beberapa manfaat dari kegiatan di atas. Pertama, fungsi pendidikannya semakin banyak anak kampung ini yang dapat menyelesaikan pendidikan tinggi di Kota Jayapura. Kedua, fungsi ekonominya makin banyak warga kampung ini yang menekuni jenis pekerjaan yang beragam yang berdampak pada membaiknya tingkat pendapatan mereka. Ketiga, fungsi kontrol sosialnya mendorong keterlibatan semua keluarga dalam mencegah gagalnya mahasiswa menyelesaikan studi akhir pada perguruan tinggi di Kota Jayapura. Keempat, fungsi kelembagaannya, makin kuatnya kegiatan arisan warga komunitas kampung ini dalam mendukung penyelesaian pendidikan tinggi di Kota Jayapura.

Manik-Manik dan Uang Sebagai Simbol Mas Kawin

Salah satu tekanan selektif pada sistem gagasan terhadap tuntutan pemenuhan kebutuhan seksual melalui relasi pada kegiatan perkawinan adalah mas kawin (dalam bentuk uang dan dinilai menengah, (3) Rau berwarna biru muda, jenis ini dinilai cukup, (4) Tuhilo berwarna kuning tua, jenis ini bernilai sedang. Juga uang dalam tertentu, maka pada saat itu pula diserahkan sejumlah uang pintu pertama (Tiloja). Penggunaan manikmanik sebagai mas kawin telah diatur sebagai berikut: ibu kandung perempuan mendapat 1 buah tuha, 1 buah turo papi, 1 buah turo pala dan 24 buah rawo. Ayah perempuan mendapat 1 buah tahe, 1 buah teropa-pi, 1 buah teropa-la dan 24 buah rawo. Pihak keluarga wanita yang lain memperoleh sesuai dengan kebutuhan mereka. Maka penggunaan manik-manik pada dasarnya menggambarkan peran keluarga terdekat terhadap keberadaan seorang wanita. Peran tersebut terutama pada seorang ibu dalam melahirkan, membesarkan, menyekolahkan dan lain sebagainya. Peran berikutnya terdapat figur ayah yang mendukung si anak sejak dilahirkan hingga sebelum berkeluarga. Juga anggota perempuannya lainnya.

Dari paparan di atas diperlihatkan bahwa penggunaan manik-manik dan uang digunakan sebagai dasar penerimaan sebuah pelamaran dari keluarga lelaki, dasar penggantian jasa seorang ibu, ayah serta saudara perempuan calon 
mempelai wanita. Itulah sebabnya besarnya nilai pengorbanan orang tua dan saudara perempuan menjadi dasar dalam penentuan besarnya nilai mas kawin yang harus dipenuhi keluarga lelaki. Kondisi ini mendorong keterlibatan semua anggota kerabat, klan lelaki bahkan warga dari luar kampung setempat, baik warga lokal serta pendatang untuk memenuhi permintaan mas kawin keluarga perempuan.

\section{Perilaku Dalam Kekerabatan}

Salah satu tekanan terhadap sistem gagasan pada relasi kekerabatan adalah sistem kekerabatan. Menurut Koentjaraningrat (1972: 209) bahwa sistem kekerabatan suatu masyarakat dapat dipergunakan untuk menggambarkan struktur sosial dari masyarakat yang bersangkutan. Struktur sosial disini dimaksudkan sebagai perumusan asas-asas hubungan antar individu dalam kehidupan masyarakat. Selain menyangkut cara berinteraksi, hal-hal yang mereka katakan dan lakukan dalam hubungan mereka satu sama lain. Tetapi juga terdapat gagasan mereka tentang pihak yang lain, konsepsi masing-masing tentang pihak yang lain, pemahaman dan strategi serta pengharapan yang menuntun perilaku mereka. Baik pola perilaku maupun sistem konseptual mempunyai struktur, dalam arti tidak kacau balau atau sembarangan, tetapi kedua hal tersebut merupakan struktur yang berbeda jenis (Keesing, 1999: 208209). Maka kekerabatan adalah merupakan unit-unit sosial yang terdiri dari beberapa keluarga yang memiliki hubungan darah atau hubungan perkawinan.

Sistem kekerabatan pada komunitas Skouw Sae bersifat patrilineal, artinya keturunan diwariskan melalui garis ayah. Sistem kekerabatan seperti di atas, terdapat pula dalam kelompok etnik Arso-Waris, Senggi, Web, Ngalum (Warasmol), dan etnik Marind-Anim. Juga dikelompokkan dalam sistem kekerabatan tipe hawai, yaitu semua saudara sepupu mempunyai istilah yang sama dengan saudara kandung. Tipe ini disebut juga generation type karena semua saudara laki-laki dan perempuan dari generasi yang sama disebut dengan satu istilah yang sama (Koentjaraningrat, 1981: 141-142). Misalnya, dalam generasi ayah seseorang, ayah orang itu, saudaranya laki-laki dan saudara laki-laki ibunya, semuanya disebut dengan istilah yang sama, yaitu 'ayah'. Demikian juga ibu seseorang, saudaranya perempuan, saudara perempuan ayahnya semua disebut dengan kata yang sama yaitu 'ibu'. Dalam generasi ego, saudara sepupu laki-laki dan perempuan dibedakan menurut kelaminnya dan disamakan dengan saudara lakilaki dan perempuan, sedangkan sistem istilah kekerabatan untuk kerabat, yang satu generasi di atas ego termasuk dalam generation type, yaitu saudara perempuan ibu mempunyai istilah yang sama dengan saudara perempuan ayah, dan saudara laki-laki ibu mempunyai istilah yang sama dengan saudara laki-laki ayah.

Kelompok kekerabatan terkecil komunitas Skouw umumnya berupa keluarga batih yang terdiri dari seorang 
ayah, seorang ibu dan anak-anak yang belum menikah. Satu keluarga batih di sini berperan sebagai satu rumah tangga, dimana mereka berusaha memenuhi kebutuhan hidup sehari-hari secara bersama dibawah pimpinan ayah dan dibantu oleh anggota klen yang telah mampu melakukan pekerjaan-pekerjaan yang dapat menghasilkan sesuatu untuk memenuhi kebutuhan hidup. Adakalanya satu rumah tangga di sini terdiri dari satu keluarga inti ditambah orang tua kandung ayah dan adik-adik ayah yang belum menikah. Hal ini terjadi jika orang tua kandung ayah dianggap tidak mampu bekerja karena sudah tua.

Perilaku pada kekerabatan terlihat pada interaksi yang berlangsung sesuai dengan peran yang melekat pada tiap orang. Hak seorang kakek menguasai lahan pewarisan dari ayahnya dan mengawasi serta mengatur pemanfaatan lahan warisan tersebut bagi anak lelakinya. Hak seorang nenek mendapatkan perawatan dari anak lelakinya dan perannya memberikan nasehat kepada anak perempuannya yang belum menikah. Hak seorang ayah menguasai lahan warisan dari ayahnya (kakek) yang masih hidup atau sudah meninggal dan perannya bekerja mencari nahkah untuk keluarga, mengikuti pertemuan adat, mengatur pewarisan lahan kepada anak laki- lakinya, merawat kedua orang tuanya dan saudara perempuannya yang belum menikah, serta mengurusi masalah eksternal keluarga. Hak seorang ibu memberikan nasehat kepada anaknya dan perannya dalam mengurusi urusan domestik seperti memasak, membersihkan rumah, dan mengasuh anak dan ekonomi keluarga melalui pembagian tugas dengan suaminya. Peran saudara lakilaki ibu mewakili keluarga saudara perempuannya mengatur segala persiapan perkawinanmulai dari menentukan dan menerima penyerahan mas kawin dari keluarga. Peranan ayah dalam perkawinan anak perempuan tidak secara langsung kecuali menentukan jumlah mas kawin dan persyaratan lain. Realitas tersebut ditemukan pula pada suku di kawasan Teluk Bintuni (Laksono, 2000: 61). Juga menerima pembayaran kepala dari anggota keluarga suami saudara perempuannya. Peranan saudara perempuan dari pihak laki-laki tampak nyata pada masa iparnya melahirkan. Mereka membantu proses kelahiran tersebut bersama-sama dengan saudara perempuan dari pihak perempuan. Hak anak lelaki mendapatkan nama klan, hak waris berupa lahan dan lain sebagainya dan perannya membantu orang tuanya mengurusi aktivitas ekonomi. Juga mengurusi dan memenuhi kebutuhan orang tuanya yang sudah tidak bisa bekerja dan saudara perempuannya yang belum menikah.Hakanakperempuanmendapatkan pewarisan pengetahuan pengaturan keluarga dan perannya membantu ibunya mengurusi urusan domestik dan ekonomi keluarga. Kewajiban cucu laki-laki dan cucu perempuan adalah mendapatkan pengetahuan budaya yang bersifat primer maupun sekunder dari kedua orang tuanya dan menghormati semua yang lebih tua dalam sistem kekerabatan dan komunitas setempat. 
Maka hubungan-hubungan sosial ini sebagai sebuah pranata yang paling banyak mengontrol perilaku lelaki dalam masyarakat. Perkawinan yang bersifat eksogami menyebabkan hubungan kekerabatan ini semakin meluas hingga ke wilayah PNG. Berdasarkan identifikasi terhadap hubungan kekerabatan penduduk di Kampung Skow Sae dan Moso, mereka mengatakan bahwa 100 persen masih memiliki hubungan kekerabatan dengan orang yang tinggal di Wutung, Mushu, Waramo, Nusuk, Yako dan Lido wilayah PNG. Jenis hubungan tersebut disebabkan karena adanya anggota keluarga atau kerabat yang kini masih menetap di PNG. Maka sistem kekerabatan mengandung fungsi sosial yang mengatur kehidupan komunitas setempat. Juga memegang peranan penting dalam organisasi produksi dan distribusi. Kekerabatan, keturunan dan perkawinan merupakan sentral dalam pembentukan berbagai hubungan perekonomian (Keesing, 1999: 210).

\section{Perdukunan}

Salah satu tekanan penting dalam pemenuhan kebutuhan keselamatan adalah keberadaan dukun. Regina adalah seorang dukun beranak yang telah menjalankan profesinya sejak tahun 1990. Pengalaman yang bersangkutan diperoleh melalui beberapa pelatihan yang dilaksanakan oleh Dinas Kesehatan Kota Jayapura dan puskesmas Distrik Muara Tami. Pelatihan tersebut juga memperkuat keberadaannya sebagai seorang dukun sekaligus mendapat 'restu' dari instansi teknis berwenang untuk melayani komunitas setempat yang belum ditangani secara baik aparat kesehatan. Perannya cukup besar pada komunitas ini karena berjasa dalam menolong ibu yang akan melahirkan dan warga yang sakit. Ketergantungan warga komunitas kepada yang bersangkutan disebabkan karena 'tidak adanya tenaga kesehatan seperti bidan dan perawat yang siap menolong para ibu yang akan melahirkan. Memang ada puskesmas, tapi hanya buka dari jam sembilan sampai jam satu siang. Sedang ibu bersalin tidak mengenal waktu. Warga Skouw sudah meminta agar puskesmas dapat buka 24 jam seperti halnya Puskesmas Koya Barat, namun permintaan ini belum terkabul hingga saat ini. Selain itu, waktu pelayanan Puskesmas yang terbatas, yakni mulai pukul 08.00-13.00 WIT, serta sering adanya beban tambahan kepada warga melalui penembusan resep obat tertentu dirasakan sangat memberatkan'

Menggunakan air panas untuk membersihkan tubuh ibu dan anak, mensterilkan gunting dan penjepit yang digunakan. Juga menggunakan minyak tawon sebagai pengganti betadine untuk mengeringkan luka pada si ibu dan untuk membantu mengeringkan tali pusat agar cepat lepas. Sementara itu, bara tempurung kelapa digunakan untuk menghangatkan pusar bayi dan luka bekas melahirkan ibu agar cepat kering. Ia juga memberikan obat minum berupa vitamin penambah darah dan antibiotik agar stamina ibu yang bersalin menjadi kuat dan mencegah infeksi yang diambilnya secara CumaCuma di puskemas Skouw. 
Dalam menjalankan prakteknya sebagai dukun anak ia tidak membebani pasien harus membayar dalam jumlah tertentu. Sebaliknya, jasanya bisa dibayar dalam bentuk hasil tegalan, seperti sagu, pisang, keladi, atau pinang. Sering menggunakan media air untuk mengobati penyakit atau kejahatan ilmu hitam. Air tersebut akan diberi mantra-mantra, kemudian diberikan kepada yang sakit untuk diminum dan ada juga yang hanya dibasuh pada bagian-bagian tubuh yang sakit dan beberapa lama kemudian warga akan sembuh'.

Selain itu, dalam hubungan dengan aspek tertentu terdapat beberapa manfaat dari interaksi dukun dengan warga. Pertama, secara ekonomi perilaku warga komunitas di atas sangat menguntungkan karena kecilnya pengeluaran untuk kepentingan ini. Berbeda apabila harus melalui pelayanan formal yang sering kali memerlukan biaya tambahan untuk memenuhi resep obat yang diberikan. Ketiga, jasa dukun bisa diberikan dalam bentuk hasil ladang atau tegalan. Warga juga tidak perlu mengeluarkan biaya transportasi untuk mendapatkan obat yang dianjurkan. Akan tetapi, cukup berjalan kaki ke rumah dukun. Kontrol sosial para dukun terhadap pasiennya juga cukup kuat. Hal ini terlihat dari pelaksanaan petunjuknya kepada pasiennya dalam proses penyembuhan. Maka secara politik peran dukun cukup besar dalam mengatur pasiennya. Mereka juga memiliki posisi yang cukup penting dalam mendukung kelembagaan tradisional khususnya dalam melestarikan pemanfaatan sumber daya alam komunitas setempat.

\section{Simbol Pemerintahan Kampung}

Salah satu tuntutan selektif untuk pelayanan dalam bidang pembangunan, pemerintahan dan kemasyarakatan adalah hadirnya pemerintahan kampung. Dalam Pasal 1 point I, bab I Ketentuan Umum Undang-Undang Republik Indonesia Nomor 21 Tahun 2001 Tentang Otonomi Khusus Bagi Provinsi Papua, disebutkan bahwa Kampung atau yang disebut dengan nama lain adalah kesatuan masyarakat hukum yang memiliki kewenangan untuk mengatur dan mengurus kepentingan masyarakat setempat berdasarkan asal usul dan adat istiadat setempat yang diakui dalam sistem pemerintahan nasional dan berada di daerah Kabupaten atau Kota. Hal tersebut berarti kampung di Papua bersifat genealogis yaitu berdasarkan asal usul keturunan yang mengelompok dalam suatu kampung. Perkampungan itu terdiri dari beberapa rumah yang dibangun secara terpisah menurut klen keluarga batih dan satu keluarga luas atau pola-pola pemukiman sesama klen. Oleh sebab itu, dalam satu kampung mempunyai hubungan consanguinal yaitu merupakan satu keturunan atau kerabat dan mempunyai hubungan dengan kampung lain, karena hubungan perkawinan serta dipimpin seorang pemimpin tradisional dari kalangan mereka sendiri. Menurut Nunem (1994) dalam satu kampung terdapat $20 \mathrm{kk}$. 
Sistem Gagasan Yang Bersumber pada Kepercayaan dan Agama

Tata atau Kati Sebagai Simbol Kepercayaan

Salah satu tekanan terhadap tuntutan kebutuhan keselamatan anggota komunitas Kampung Skouw Sae adalah aspek kepercayaan yang ikut mempengaruhi kehidupan mereka. Sebelum agama Kristen Protestan masuk ke wilayah ini, warga telah memiliki kepercayaan terhadap seruling suci (puu) yang diyakini memiliki nilai magis yang sangat tinggi dan merupakan suatu tanda keberkatan bagi tiap anggota komunitas. Terdapat pula kepercayaan adanya suatu kekuatan yang melebihi kekuatan manusia biasa (Tata atau Kati) yang menciptakan, memelihara, serta menjaga mereka selama hidup dan beraktivitas di alam ini. Mereka juga percaya arwah nenek moyang yang telah meninggal tinggal di rumah adat yang mengontrol kehidupan manusia (termasuk warga kampung ini). Maka semua anggota komunitas mempunyai kewajiban untuk menghormati kepercayaan tersebut. Itulah sebabnya, segala aktivitas yang melibatkan massa yang banyak selalu dilakukan dalam tempat tersebut.

Dari pemaparan di atas diperlihatkan bahwa kepercayaan sebagai sistem gagasan memiliki beberapa manfaat. Fungsi pendidikannya mewariskan kepercayaan tersebut agar tidak hilang dengan munculnya keyakinan keagamaan melalui kegiatan ritual tiap tahun. Kondisi tersebut pada akhirnya memperkuat relasi dengan nenek moyang, relasi antar marga, relasi dalam perkawinan, relasi dalam kekerabatan, relasi dengan pemimpin tradisional, relasi dengan pemimpin formal, relasi dalam kegiatan ekonomi, relasi dengan kependetaan, relasi dengan pelayanan kesehatan, relasi dengan dukun, relasi dengan dunia pendidikan serta relasi dengan kegiatan pada rumah adat. Kedua, hal tersebut berfungsi mempertahankan integrasi kesatuan sosial yang memiliki eksistensi. Fungsi kelembagaannya mempertahankan peran pesuruh dalam kegiatan ritual dalam rumah adat. Dengan kewenangan sanksi yang dimilikinya membuat kegiatan tersebut berjalan dengan lancar.

\section{Pawai Obor Paskah Sebagai Perilaku Keagamaan}

Salah satu tekanan terhadap tuntutan pemenuhan kebutuhan integrasi individu komunitas kampung ini adalah melalui perayaan pawai obor paskah. Kegiatan belakang di atas sebagai sistem gagasan bagi komunitas ini memiliki peran penting karena digunakan untuk mengabsahkan, mengatur dan menuntun perilaku mereka. Oleh sebab itu, lambanglambang keagamaan digunakan untuk memadukan, merekatkan bersama lembaga dan kumpulan lembaga ke dalam suatu keutuhan yang padu. Agama Kristen Protestan pertama kali dibawa penginjil yang bernama Yohanes Mahulete (komunitas lokal menyebut Malute) ke wilayah Skouw pada tanggal 14 September tahun 1914. Dia juga sebagai orang luar pertama yang menetap dalam waktu lama. Sementara itu, agama Kristen Protestan masuk ke wilayah Kampung Skouw Sae 
dibawah guru jemaah yang bernama Bapak Noak Kabey. Dampak penting kehadiran agama di wilayah ini adalah munculnya keyakinan warga komunitas setempat yang menjadikan Yesus Kritus Sebagai Juru Tuhan dan Juru Selamat. Mereka juga sama-sama menerima Allah sebagai Kasih sehingga mengharuskan mereka untuk saling mengasihi. Hal tersebut membawa konsekuensi pada munculnya kebiasaan warga melakukan pawai obor mengelilingi kampung sehari sebelum perayaan Natal atau Paskah.

Hal di atas menggambarkan bahwa pawai obor yang dilaksanakan sebelum perayaan Paskah pada dasarnya berupa emosi keagamaan yang didapatkan dari kegiatan keagamaan ataupun pendalaman agama sehingga menyebabkan mereka menjadi religius. Oleh karena itu, pawai obor menjelang perayaan Natal atau Paskah sebagai wujud penerimaan ajaran Kristen Protestan dalam kehidupan mereka, khususnya dalam memperkuat perasaan kasih terhadap sesama. Hal tersebut telah melahirkan perilaku toleran yang terwujud dalam berbagai kegiatan seperti suka bertamu pada hari besar keagamaan, terlibat bersama dalam membangun rumah ibadah.

\section{Tarian Bajo, Wo, serta Mandep sebagai Simbol Kesenian}

Salah satu tekanan terhadap tuntutan pemenuhan kebutuhan integrasi anggota komunitas kampung ini untuk sama-sama memiliki 'ritme komunal' dalam kehidupan dan aktivitas adalah kesenian. Tarian bajo, wo, serta mandep merupakan simbol kesenian komunitas kampung ini yang pementasannya dalam suasana dan tujuan tertentu dengan melibatkan semua warga yang hadir. Jenis tarian bajo dipentaskan saat mengantar atau menjemput warga yang telah selesai melakukan kegiatan perburuan dengan tujuan sebagai ungkapan rasa syukur atas tugas ondoafi yang dibebankan kepada mereka. Jenis tarian wo digunakan untuk mengantar jenazah pemimpin tradisional ke rumah adat sebelum dikuburkan. Menurut kepercayaan komunitas ini, jenazah pemimpin mereka harus mendengarkan nyanyian dan bunyi tabuhan tifa untuk terakhir kalinya sebelum dimakamkan. Jenis tarian mandep biasanya dipentaskan pada upacara pelantikan ondoafi, serta pembuatan rumah adat. Jenis tarian belakangan ini juga mengisahkan perjalanan sebagian warga komunitas ini dari Kampung Wutung. Pementasan ketiga jenis tarian tersebut dilakukan kelompok penari laki-laki dan wanita serta diikuti warga secara bersama. Terdapat pula seni ukir yang dimiliki kedua komunitas ini. Namun, kini kegiatan mengukir, jenis ukiran atau motif ukuran sudah jarang dijumpai. Hanya beberapa orang saja yang masih menyimpan jenis ukiran tersebut. Seni mengukir pada masa lalu biasanya dilakukan pada perlengkapan perang dengan motif burung, ular, serta soa-soa. Selain itu, kegiatan mengukir ketiga obyek tersebut dilakukan juga pada perahu, tifa, dan dinding rumah. Hal tersebut disebabkan dalam kehidupan komunitas setempat, ketiga hewan tersebut dijadikan sebagai bahan makan sumber protein. Maka fungsi ketiga jenis tarian 
tersebut sebagai ritme komunal untuk memperkuat hubungan kekerabatan, klan, komunitas dalam kaitannya dengan kepercayaan, sejarah asal mula sebagian warga kampung ini serta melanggengkan kedudukan pemimpin tradisional dalam kehidupan kampung ini.

\section{Perilaku Upacara Sekitar Lingkaran Hidup}

Salah satu tekanan terhadap lahirnya kebutuhan keamanan tiap warga adalah lahirnya perilaku upacara sekitar lingkaran hidup. Misalnya, upacara saat bayi masih dalam kandungan, kelahiran, cukur rambut, masa kanak-kanak, serta inisiasi. Sekarang kebanyakan upacara tersebut dirubah dalam bentuk pengucapan rasa syukur di gereja. Terdapat pemahaman dari warga bahwa upacara saat kelahiran telah disejajarkan dengan upacara pembaptisan kudus di gereja. Upacara inisiasi disejajarkan dengan upacara peneguhan sidi di gereja. Hal tersebut menyebabkan seluruh fungsi dan peranan wowo dan fafa dalam konteks adat telah dialihkan ke dalam kegiatan gereja sebagai wali. Selain itu, apabila salah seorang mengalami kedukaan, maka anggota tersebut belum boleh keluar rumah sebelum melakukan pengucapan syukur (makan bersama) dengan mengundang seluruh kerabat dan anggota majelis untuk mendoakan keluarga tersebut.

Perlunya dilakukan upacara berkaitan dengan lingkaran hidup manusia didasari pemahaman bahwa semua masa peralihan dianggap masa krisis, dimana manusia harus melepaskan diri dari suatu lingkungan sosial yang lama, kemudian harus melampau suatu masa peralihan, dimana ia sebagai makluk lemah tanpa identitas dan tanpa kedudukan harus mempersiapkan diri secara jasmaniah maupun rohaniah untuk kedudukannya nanti dalam suatu lingkungan sosial yang baru. Dalam keadaan peralihan semacam itu, banyak kemungkinan orang bisa terserang berbagai macam bahaya seperti sakit, maut dan lain-lain bencana yang tidak dapat dikuasainya dengan akalnya. Oleh karena itu, dalam menghadapi masamasa krisis seperti itu, manusia bersikap penuh waspada dan prihatin, dan perlu tindakan-tindakan untuk memperteguh imannya serta memperkuat mentalnya. Tindakan-tindakan itu berupa upacara yang kini dilakukan dalam nuansa keagamaan di dalam gereja. Maka upacara itu bukan peristiwa biasa, tetapi peristiwa yang dilaksanakan dengan emosi keagamaan.

\section{PENUTUP}

Dari pemaparan sebelumnya diperlihatkan bahwa sistem gagasan yang dipakai untuk mengabsahkan, mengatur dan menuntun perilaku mereka begitu banyak serta mencakup hampir semua aktivitas dalam kehidupan individu, keluarga dan komunitas. Penciptaan sistem gagasan yang berlangsung selama adanya komunitas ini telah memegang peranan penting dalam memadukan, merekatkan bersama lembaga dan kumpulan lembaga ke dalam suatu keutuhan yang satu padu. Sebagai dasar dan pandangan hidup yang 
terkait dengan kehidupan komunitas, serta komunitas. Juga menjadi penuntun maka sistem gagasan tersebut juga dalam menjaga kepentingan keluarga, klan telah memegang peranan penting dalam serta komunitas secara umum. Akhirnya meletakkan pondasi yang kokoh bagi sistem gagasan telah memegang peranan komunitas kampung ini dalam melakukan penting dalam melanggengkan kehidupan aktivitas kehidupan individu, keluarga komunitas ini.

\section{DAFTAR PUSTAKA}

Boelaar, J. 1986. Manusia Irian. Jakarta: PT Gramedia.

Budisanto, Y. 1986. Antropologi Politik Georges Balandier. Jakarta: CV. Rajawali

Keesing, Roger M. 1999. Antropologi Budaya Suatu Perspektif Kontemporer. Jakarta: Penerbit Erlangga.

Koentjaraningrat. 1972. Beberapa Pokok Antropologi Sosial. Jakarta: Penerbit Dian Rakyat.

Koentjaraningrat. 1981. Antropologi Sosial. Jakarta: PT. Dian Rakyat.

Koentjaraningrat. 1984. Kamus Istilah Antropologi. Jakarta: Pusat Pembinaan dan Pengembangan Bahasa Departemen Pendidikan dan Kebudayaan.

Laksono, P. M. et.al. 2000. Perempuan di Hutan Mangrove Kearifan Ekologis Masyarakat Papua. Yogyakarta: Galang Press.

Nunem, OFM, Alfons Van. 1994 Aspek-aspek sosial budaya dalam proses integrasi, Kebudayaan dan Pembangunan di Irian Jaya, E.K.M. Masinambow \& Paul Haenem (ed.). Jakarta: LIPI-RUI. Hal. 39-48

Poespowardojo, Soerjanto. 1989. Strategi Kebudayaan Suatu Pendekatan Filosofis. Jakarta: Penerbit PT Gramedia.

Turner, Jonathan H and Alexandra Maryanski. 2010. Fungsionalisme (terj). Jogjakarta: Pustaka Pelajar.

Suparlan, Parsudi. 1995. ”Keaneragaman Kebudayaan Irian Jaya, Strategi Pembangunan dan Transformasi Orang Irian ke Dalam Masyarakat Indonesia”, dalam Proseding Seminar Membangun Masyarakat Irian Jaya. Jakarta: Puslitbang Kependudukan dan Ketenagakerjaan Lembaga Ilmu Pengetahuan Indonesia.

Veplum, Dirk. 2008. Partisipasi Komunitas Lokal Terhadap Pembangunan Wilayah Perbatasan Antara Republik Indonesia dan Papua New Guinea di Provinsi Papua (RI-PNG). Jayapura: Universitas Cenderawasih.

Veplum, Dirk. 2010. Pemberdayaan Komunitas Lokal Terhadap Pembangunan Wilayah Perbatasan Antara Republik Indonesia dan Papua New Guinea di Distrik Muara Tami Kota Jayapura, Jayapura: Universitas Cenderawasih.

Warren, Carol. 2002. "Membangkitkan Hak Ulayat: Pemetaan Partisipatif, Kedaulatan Masyarakat Adat, dan Peranan Mediatornya pada Era Reformasi" dalam Berebut Tanah Beberapa Kajian Berperspektif Kampus dan Kampung. Yogyakarta: Insist Press. 